\title{
CARS/ALK Fusion Gene
}

National Cancer Institute

\section{Source}

National Cancer Institute. CARS/ALK Fusion Gene. NCI Thesaurus. Code C99871.

A fusion gene that results from a chromosomal translocation $\mathrm{t}(2 ; 11)(\mathrm{p} 23 ; \mathrm{p} 15)$ which fuses most of the CARS gene with the last ten exons of the ALK gene. This fusion is associated with both inflammatory myofibroblastic tumors and anaplastic large cell lymphoma. 